\title{
EFFECT OF SOCIAL MEDIA USE ON ADOLESCENT MENTAL HEALTH IN KENDARI, SOUTH EAST SULAWESI
}

\author{
Putu Suri Saraswati, Rismawati \\ Masters Program in Public Health, School of Health Sciences Mandala Waluya, Kendari
}

\begin{abstract}
Background: Social media is constantly running in the background of life. According to a British Psychological Society, approximately 90 percent of teenagers are on social media. Constantly seeing what their peers are doing on a day to day basis can be damaging to their mental health. This study aimed to determine the effect of social media use on adolescent mental health in Kendari, South East Sulawesi.

Subjects and Method: A cross sectional study was conducted at three RTs in Rahandouna village, Kendari, South East Sulawesi. A total sample of 48 adolescents was selected for this study by multi stage random sampling. The dependent variable was mental health. The independent variable was use of social media. The data were collected by questionnaire and analyzed by chi-square with prevalence ratio (PR) as the measure of association.

Results: Emotional problem ( $\mathrm{PR}=1.89$; CI 95\% 0.90 to $3.97 ; \mathrm{p}=0.041)$, self control inadeptness ( $\mathrm{PR}=2.74$; CI 95\% 0.97 to $7.78 ; \mathrm{p}=0.018)$, social life ignorance ( $\mathrm{PR}=1.78$; $\mathrm{CI}$ $95 \% 0.95$ to $3.36 ; \mathrm{p}=0.025)$ and time intensity $(\mathrm{PR}=3.16$; CI $95 \% 1.13$ to $8.84 ; \mathrm{p}=0.003)$ were associated with mental health issues related to social media. The association between neglected work or activity and mental health issue related to social media was not statiscally significant ( $P R=1.65$; CI 95\% 0.77 to $3.51 ; \mathrm{p}=0.145)$.

Conclusion: Most of adolescents are classified as actively using social media. Emotional problem, self control inadeptness, ignoring social life, and time intensity are associated with mental health issues related to social media.
\end{abstract}

Keywords: social media, mental health, adolescent.

\section{Correspondence:}

Putu Suri Saraswati. Masters Program in Public Health, School of Health Sciences Mandala Waluya, Jl. A.H.Nasution No. G 37, Kendari, South East Sulawesi

Email: surisaraswati@gmail.com. Mobile: 081943396856.

The $5^{\text {th }}$ International Conference on Public Health Best Western Premier Hotel, Solo, Indonesia, February 13-14, 2019 | 176 https://doi.org/10.26911/theicph.2019.02.21 